\title{
Contribution of applied geophysics in mining prospecting
}

\author{
Meryeme El Abidi El Alaoui ${ }^{1}$, Latifa Ouadif ${ }^{1}$, Lahcen Bahi ${ }^{1}$, Ahmed Manar $^{2}$ \\ ${ }^{1}$ L3GIE, Ecole Mohammadia d'Ingénieurs, Université Mohammed V-Rabat \\ ${ }^{2}$ Ministère de l'Energie, des Mines et du Développement durable- Rabat
}

\begin{abstract}
The Eastern High Atlas (Morocco) contains a variety of rocks with different magnetic susceptibility, among these rocks are those which constitute the Proterozoic and Paleozoic basement of the plain of Tamlelt which is the study area. This work is devoted to the analysis and interpretation of the main magnetic anomalies using the Oisis Montaj program, and the correlation using ArcGis software, from the main " magnetic facies» detected, to the main geological formations affecting the geological basement, highlighted in the plain of Tamlelt. The map of the residual magnetic field shows elongated magnetic anomalies in the direction E-W and NE-SW. the reduction to the pole shows at the level of the plain of Tamlelt a large anomaly elongated in the direction E-W then in the direction NW-SE. The transformation of Tilt Angle allowed to delimit the anomalies of low or high amplitude that limit the shallow structures. The quantitative interpretation of the main magnetic anomalies highlighted in the study area has made it possible to characterize the deep structure of the magnetic bodies, which could contain sulphide clusters, according to the geological and mining context of the studied area.
\end{abstract}

\section{Introduction}

The demand for natural resources is increasing globally, hence the use of innovative techniques to explore all viable resources to meet this growing need. Indeed, geophysics is an essential tool for studying geology at medium and great depths, since the easiest deposits to discover have already been and because we are interested to deeper depths, also to areas that mineral resources has not been discovered. Consequently, this work is devoted to the quantitative interpretation of the main magnetic anomalies revealed in the plain of Tamlelt located

\section{Geology setting}

The Eastern High Atlas at the extreme south-east of Morocco, is composed of narrow parallel mountain ranges, which are oriented E-W framing two plains separated by outcorps of formations of the Triassic: the plain of Tamlelt in the West and the plain of Figuig in the East [1]. The Eastern High Atlas extends from the east of the city of Bou Arfa to the Moroccan-Algerian border. The geological formations correspond, in the west, to the plain of Tamlelt and the Saharan Atlas to the east [3]. and because we are interested to deeper depths, also to areas that mineral resources has not been discovered. Consequently, this work is devoted to the quantitative interpretation of the main magnetic anomalies revealed in the plain of Tamlelt located in the Eastern High Atlas in order to characterize the deep structure of the magnetic bodies, which could contain sulphide clusters given the geological and mining context of the sector studied.

in the Eastern High Atlas in order to characterize the deep structure of the magnetic bodies, which could contain sulphide clusters given the geological and mining context of the sector studied.

The plain of Tamlelt, is located in the south of the internal domain of the Hercynian chain and north of the cratonic of Africa. It corresponds to the Paleozoic transforming zone of the Atlas [5]. The Tamlelt plain played an important role in the sedimentary deposits of the Eastern Atlas from primary. Indeed, this plain which is currently a depressed area in altitude compared to the High plateau which border in the north, constituted since the Precambrian, a high relief on the edges of which came to be beveled the successive deposits of Primary and Jurassique. This phenomenon is particularly clear at the lower Lias where the reef facies are developed on the edges of the ancient massif, the throughout the Jurassic whose successive levels rely on previous transgressive stratigraphic bevels; the Tamlelt then behaved on the threshold, rounded to the $\mathrm{N}$ and $\mathrm{S}$ by two narrow marine depressions which communicated 
the High Atlas to the $\mathrm{W}$ and the Saharan Atlas to the E. the Atlas orogeny probably elevated this massif high enough, then an active subsidence which is still continuing today brought this part which was the most in relief of the chain in a zone lower than its edges [2].

At the structural level, the plain of Tamlelt is a remarkable high point, this internal depression seems to have to be explained a much by ancient geological history as by its tectonic behavior during Tertiary and Quaternary times. During the Jurassic the thicknesses of the deposits confirm the existence of a threshold (the Tamlelt) separating longitudinally the regions of the High Atlas located to the west of the Saharan Atlas to the east. The Hercynian tectonics of the region is marked by two episodes of ductile deformation, the first eovaric recognized by Hoepffner (1987) and Houari and Hoepffner (2000) and in the northern domain is taken up by a more moderate phase attributed by the same authors to the Namuro-Westphalian phase. In the centro-southern area, which is south of the first, only the Namuro-Westphalian phase is expressed. The ductile phases are followed by a major late-Hercynian dislocation, which generates shear corridors where the interior structures are twisted into sigmoidal patterns. [5]

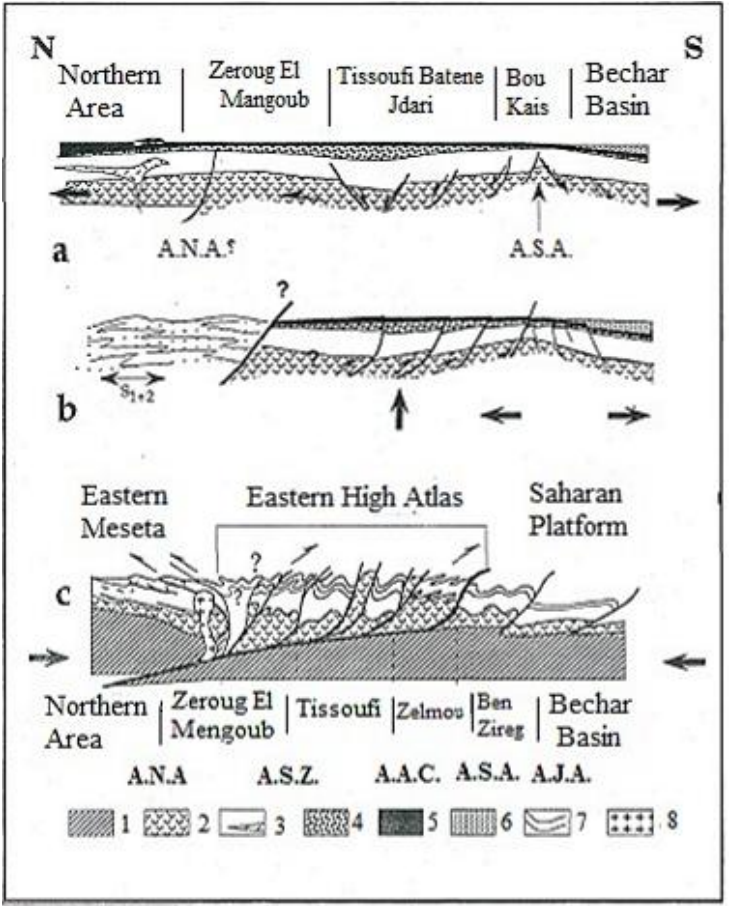

Fig1. Hercynian tectonic evolution of the buttonhole of Tamlelt (Houari Hoepffner 2000)

Legend 1- Crystalline socle of Proterozoique age; 2volcano-sedimentary deposits of the upper Proterozoic; 3Cambro-Ordovician formed dolomites and limestones of the Lower Cmbrian with sandstone lateral variantions at the Bou Kis zone, shales, sandstone in the southern domain, plus green rocks in the northern domain; 4Sandstone and microconglomerate quartzites of the terminal Ordovician; 5- Silurian schists; 6- Devonian and Carboniferous of the Saharan platform; 7-

Undifferentiated Paleozoic cover; 8- Tigri chot granite and Orak microgranite. A.S.Z : Accident South Zeroug; A.N.A: North Atlas accident; A.N.Z: Accident North Zroug; A.A.C: Accident of Ain Chair; A.S.A: South Atlas Accident; A.J.A: Accident of Jbel Antar.

From the Devonian, the area behaved at the sill and at the bottom in relation to deposits that accumulate further south (a). In the superior Devonian; folding of the northern domain by the evorasic phase. The curling is done in a direction E-W (b). Generalized P3 fold followed by flaking, especially in the area of Zroug El Mengoub (c). [5,7]

In the Mougueur and the northern border of Tamlelt, sandstones and shales probably medium Cambrian, are affected by synschistous fundamental folds of axis NW-SE to NNW-SSE (N130-160E) dumped at SW, sub contemporary shears in the axial planes.

These structures, probably evorasic, are taken up by NE-SW folds at E-W. In the center and south of the Tamlelt buttonhole, a Carboniferous age deformation combining overlaps and setback, which gives rise to ENE-WSW folds, synschistous, dumped at the SSE associated with transversal dextral faults oriented E-W. This deformation, which only involves inferior Paleozoic formations, probably corresponds to that recorded in the Carboniferous of Bechar and Tineghir. These regions correspond to the SE margin of the Hercynian chain, characterized in particular by the absence of granitoids and a relatively moderate shortening not involving the entire crust. [9]

The plain of Tamlelt is an open indentation in the Mesozoic cover, the Atlasic deformation around the buttonhole is generally comparable to that of the High Atlas, and these are very narrow and acute anticlinal folds separating very large synclines to flat bottom. The only witness to these structures that affected the center of the buttonhole is the synclinal Jbel Tamsahlet in the form of concentric undulations of half-length about a kilometer, Jbel Talmeust borders the western part of the buttonhole, the cliffs are sub-horizontal, in reality they correspond to a broad periclinal termination with a low dip towards the west On the other side, the anticlines are often tight (anticlines El Hirech and Ben Yatti). In the eastern part, the Mesozoic slab is almost tabular fractured by Faults N85 and $\mathrm{N} 45$, the synclinal folds of atlasic style, begin to 
appear in the superior Jurassic and Cretaceous formations of the Ich region. The maximum deformation is focused on the borders of tamlelt, the folds are dumped towards the outside of the chain, the short flanks evolve in an important overlap with detachement (collapses structures) as in Jbel Haouanite, and Jbel Antar and Jbel Horreit to the south near the Talzaza massif. These overlaps are associated with a clearly observable dextral strike component near Bou Arfa to Jbel l'Orak; an intense network of subparallel E-W faults crisscrosses the northern border. The southern border of the pit of Tamlelt would be the northern accident Zroug (A.N.Z). [5]

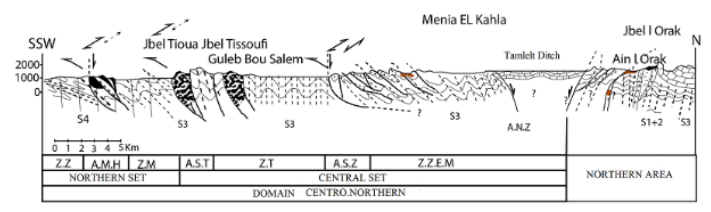

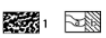

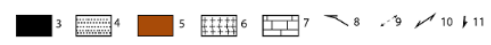

Fig2: Synthetic structural section through the plain of tamlelt (Houari and Hoapffner 2000)

Legend 1-Metavolcanite and superior Proterozoic andesite; 2-Cambro-Ordovician; a-schists; b-dolomite and Georgian limestones of Jbel Tioua; 3-terminal sandstone Cambrian Hassi Douis terminal; 4-sandstone and quartzite microconglomerate of the superior Ordovician; 5-Siluria, schists; 6-microgranite from Orak; 7-Paleozoic post cover; 8- post-fold overlaps; 9-dextral setback post-fold; 10-Mnijel; Z.T-Tissoufi area; Z.Z.E.M -zone of Zroug El Mengoub

The Paleozoic buttonhole of Tamlelt is characterized by gold mineralization on its southern border (Tamlelt-Menhouhou deposit), two mineralizations auriferous minerals could be identified: (i) Iron Oxide primary gold mineralization Copper Gold deposit "(IOCG) associated with sodium ( \pm calcium) alteration characterized by enrichment in $\mathrm{Au}, \mathrm{Cu}, \mathrm{Fe}, \mathrm{Co}, \mathrm{Ni}$, $\mathrm{Mo}, \mathrm{As}, \mathrm{Sb}, \pm \mathrm{Bi}$, and (ii) gold mineralization secondary "Shear zone related gold deposit" type associated with argillaceous alterations and phyllitous located along the decro-overlaps. Barytic mineralization and Iron type "Banded Iron Formations" could identified.

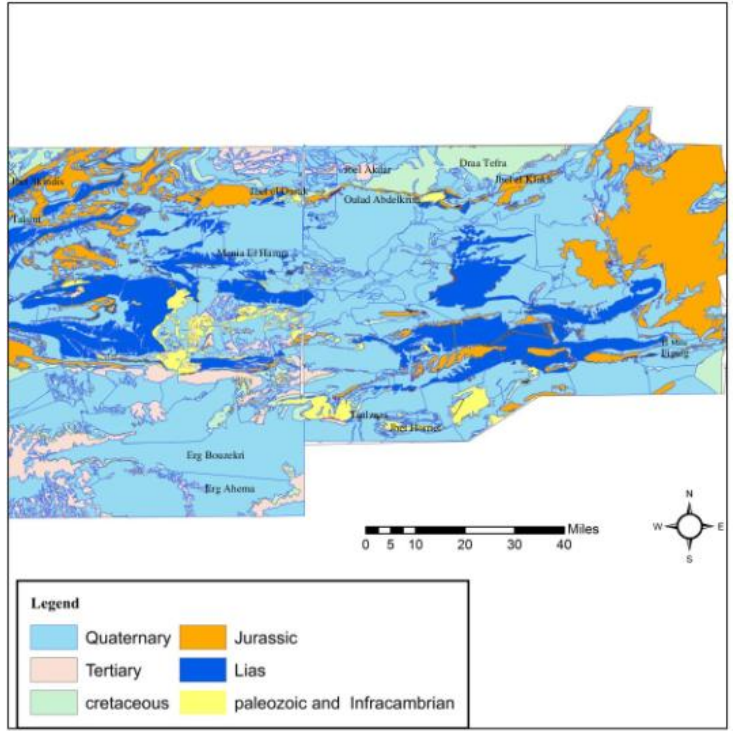

Fig.3: Geological map of the plain of Tamlelt

\section{Data and methods}

\section{Aeromagnetic data}

The airborne magnetic data used for this study were obtained from the Ministry of Mines and Energy of Rabat in the form of a database containing the total field. These data result from an aeromagnetic study carried out by the African Geophysical company in 1970 in the Eastern high Atlas. The data was acquired by C.S.F Caesium Steam magnetic equipment onboard a Grand Commander Type 680 FL aircraft. The aeromagnetic survey carried out consists of NW-SE steering flight lines spaced 3.5 to $4 \mathrm{~km}$ and NE-SW transverse direction lines with a spacing of 10 to $15 \mathrm{~km}$.

\section{Separation of the residual and the regional}

Regional-residual separation is one of the key elements in the interpretation of gravimetric and magnetic data. Several methods have been proposed, namely the graphical method, the vertical gradient, the nonlinear filters, the wavelet filters and the inversion of the regional structure. [14]

The graphical approach was initially limited to the analysis of profile data and, to a lesser extent, mesh data. The first graphical approach considered the 
regional field at one point as being the average of values observed around a circle centered on the point; the residual field was simply the difference between this mean value and the value observed at the central point. [15]

For this, the international Geomagnetic Reference Field (IGRF), which represents the regional magnetic effect, has been calculated by the IGRF module included in the Oasis montaj software, which has been defined as inputs : survey date, longitude, latitude and the elevation of the measurement points, and as output: the IGRF, the inclination and the declination. This field used to calculate the residual magnetic field which is only the subtraction of the IGRF from the total field.

$$
\begin{aligned}
& T=I G R F+d T \\
& d T=T-I G R F
\end{aligned}
$$

With:

\section{T: Total magnetic field;}

dT: Residual magnetic field;

IGRF: International Geomagnetic Reference Field;

The map of the residual magnetic field revels positive and negative anomalies of different shapes and amplitudes which testify to the variation of the magnetization in the subsoil [13]. In order to better visualize these magnetic anomalies and facilitate the analysis and structural interpretation of the results of the treatments were performed using filters and operators based on the mathematical software.

The magnetic anomaly depends in addition to the local parameters of the field terrestrial magnetic: inclination, declination and intensity. To simplify the form of the magnetic anomaly, Baranov (1957) and Baranov \& Naudy (1964) proposed an approach mathematical known by the reduction to the pole that is calculated in the field of frequency using the following filter operator.

$$
\begin{gathered}
L(\theta)= \\
\frac{[\sin (I)-i \cos (I) \cos (D-\theta)]^{2}}{\left[\sin ^{2}\left(I_{a}\right)+\cos ^{2}\left(I_{a}\right) \cos (D-\theta)\right] \cdot\left[\sin ^{2}(I)+\cos ^{2}(I) \cos (D-\theta)\right]}
\end{gathered}
$$

I: Geomagnetic inclination;

$I_{a}$ : Inclination used for amplitude correction, it is greater than or equal to I;

D: Geomagnetic declination;

$\Theta$ : Azimuth of the wave number in degrees ; $\mathrm{i}$ :Complexe number such that $\mathrm{i}=\sqrt{-1}$;

The reduction of magnetic anomalies at the pole uses a complex operator composed of two parts, one real and the other imaginary. This reduction makes it possible to eliminate the distortion of the anomalies caused by the inclination of the Earth's magnetic field by transforming the magnetic anomaly as if it were located at the North Magnetic Pole and to put the anomalies back on top of the sources which create them, to condition that the magnetization is not persistent. $[13,17,19]$

In order to achieve this reduction we calculated the inclination and the declination of the study area, their values are respectively $43.5^{\circ} \mathrm{N}$ and $-0.7^{\circ} \mathrm{W}$.

\section{Tilt Angle transformation}

The Tilt-Angle transformation calculates the inverse of the tangent of the ratio of the horizontal partial derivative and the vertical derivative module of the magnetic field. The advantage of the tilt angle is that it does not require knowledge of parameters such as density, magnetic susceptibility, structural index or other. Used for mapping shallow structures of the subsoil and mineral deposits target during an exploration. [15] [17]

$$
\theta=\tan ^{-1} \frac{\frac{\partial M}{\partial Z}}{\sqrt{\left(\frac{\partial M}{\partial x}\right)^{2}+\left(\frac{\partial M}{\partial y}\right)^{2}}}
$$

$\mathrm{M}$ being the grid of the field or the magnetic anomaly.

The usefulness of this transformation operator resides in the fact that it enhances all the magnetic anomalies to be low or high amplitudes, indeed another advantage of the transformation is that by calculating an angle, all the forms will be represented in ways similar, whether the anomalies are of low oh high amplitude. The operator is applied to the map of the magnetic anomaly reduced to the pole; for a vertical contact, the null value of the angle corresponds to the limit of the structure. $(\mathrm{h}=0)$.

\section{The Euler Deconvolution}

The Euler Deconvolution is a filtering method that allows the location of sources of anomalies in depth. In application of this method of filtering, the Eulerian solutions are calculated following 
structural indices (SI) fixed according to the sought objective, for the contacts and the faults the structural index which one used is 0 . [17]

Thompson 1982 developed a method for analyzing potential field data based on the properties of the functions governing these fields. He found that these functions generally meet the homogeneity criteria of the Euler equation. This method allows the localization of anomalies in the horizontal plane as well as the estimation of their depth $[16,19]$.

The principal of the method is based on the resolution of the above equation which has four unknowns: $\mathrm{x} 0, \mathrm{y} 0, \mathrm{z} 0$ and $\mathrm{B}$. $\mathrm{x} 0, \mathrm{y} 0, \mathrm{z} 0$ : represent the position of the equivalent point source responsible in part for the anomaly detected.

Let us consider a source $\mathrm{S}$ situated at the point $\mathrm{M}$ of coordinates $\mathrm{x} 0, \mathrm{y} 0, \mathrm{z} 0$, the magnetic field or gravimetric intensity at the observation point $\mathrm{P}$ of the distance M-P.

$$
T(x, y)=f\left[\left(x-x_{0}\right),\left(y-y_{0}\right),\left(z-z_{0}\right)\right] .
$$

$(\mathrm{x} 0, \mathrm{y} 0, \mathrm{z} 0)$ : Position of the magnetic source;

T: Total field $\mathrm{T}$ that is detected at $(\mathrm{x}, \mathrm{y}, \mathrm{z})$;

B: Regional value of the total magnetic field;

N: Degree of homogeneity often called structural index (IS) which characterizes the source type and the rate of variation of the field as a function of distance.

\section{Results and discussion}

The residual magnetic field map (fig.7) shows elongated anomalies along the NW-SE direction with a positive pole, whose magnetic field values can reach $85.51 \mathrm{nT}$, and another significant EW direction anomaly representing a negative pole, of which the amplitude oscillates between -131.82 nT and $-0.24 \mathrm{nT}$.

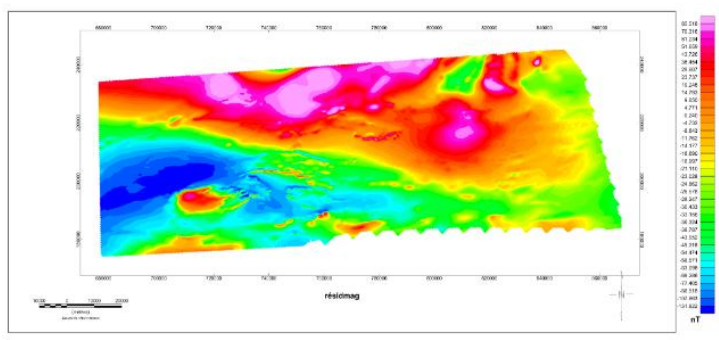

Fig.7: Map of the residual magnetic field of the study area

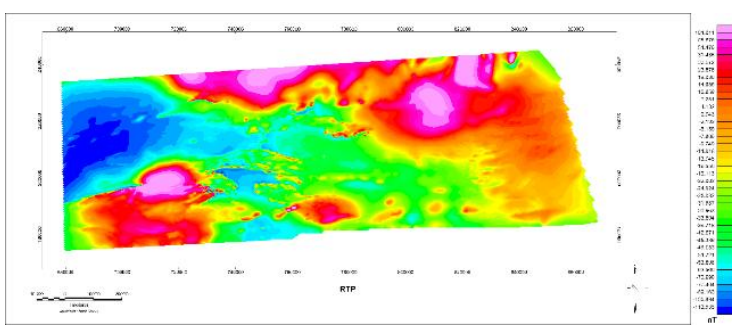

Fig.8: Map of the residual magnetic field reduced to the pole

The reduced at the pole shows, at the level of the Tamlelt plain (fig.8), a large anomaly (strong values in red to pinkish) elongated along the direction EW and then in the direction NW-SE (fig), the values of the field Magnetic range from 111.58 to $103.64 \mathrm{nT} / \mathrm{m}$. in order to determine the geological source of the magnetic anomalies, the geological map was superimposed on the magnetic data reduced to the pole. The plain of Tamlelt at the level of the important magnetic anomalies shows in outcrop formations of the Paleozoic (formation gréso-quartzique and schisto-gréseuse of the Ordovician).

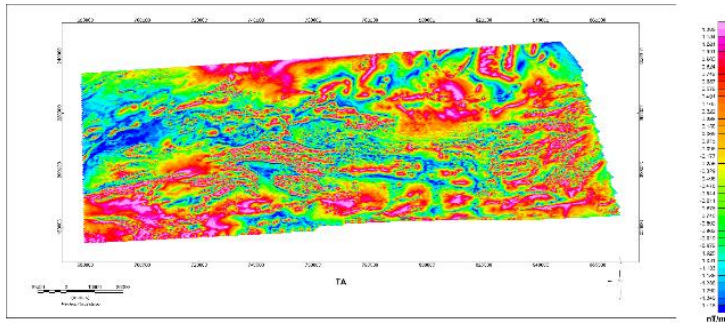

Fig.9: Tilt-Angle map of the study area

The map of the Tilt-angle transformation (fig.9) shows the curve of the contact-equivalent angle $\theta$, which limits elongated structures oriented E-W to NW-SE in the Tamlelt plain. At these structures there is a positive variation of the angle from $0^{\circ}$ to $1.178^{\circ}$ which corresponds to the range of orange to pink color. In the Tamlelt plain, the lineaments of the Tilt-angle transformation limit the most important anomaly E-W (Ain Chair-Mengoub), this transformed map represents an analogy with the geological structure of the basement of the study area

The application of the "Euler Deconvolution" filter on the reduction at the pole requires the preparation of the three main derivatives in three axes $\mathrm{X}, \mathrm{Y}$ and $\mathrm{Z}$.

The first horizontal derivative, along the $\mathrm{X}$ and $\mathrm{Y}$ axis, of the residual magnetic field reduced to the pole represents the rate at which this magnetic field varies along these two horizontal axes. The calculation of the first $\mathrm{X}$-axis horizontal derivative 
(Fig.4) highlighted the N-S elongated structures, and the $\mathrm{Y}$-axis derivative (Fig.5) of the elongated W-E structures.

The first vertical derivative of the magnetic field represents the rate at which the magnetic field varies according to the depth (fig.6). Calculation of the first vertical derivative removes the long wavelength components of the magnetic field and greatly improves the resolution of near or overlapping anomalies. One of the properties of the first vertical derivative maps is the coincidence of the zero value curve and vertical contacts at high magnetic latitudes. [16,19]

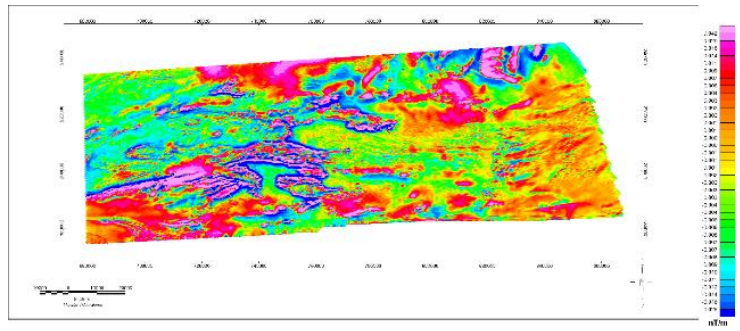

Fig.4: Map of the horizontal derivative along the axis (X)

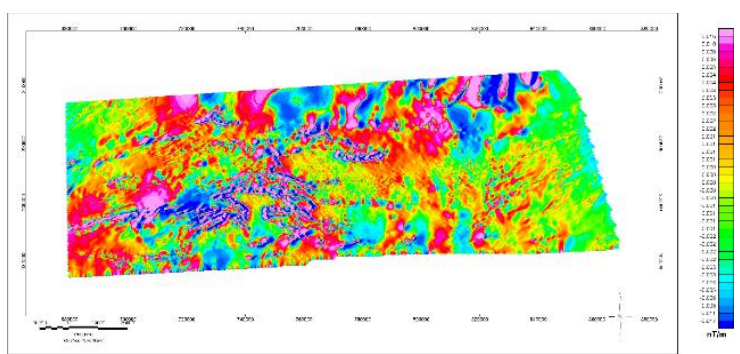

Fig.5: Map of the horizontal derivative along the axis (Y)

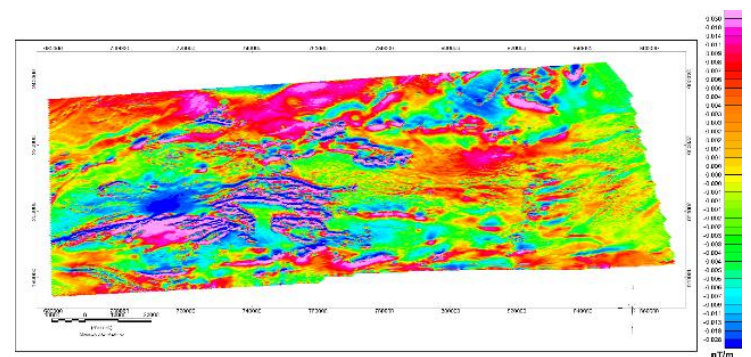

Fig.6: Map of the vertical derivative along the axis (Z)

The next step is the calculation of the Euler solution from the Euler3D extension in Oisis Montaj, using the three aforementioned derivatives and using the structural index (SI) according to the geological model. For the calculation of the depth of the magnetic anomaly, we have opted for a structural index equal to 0 : Linear (faults and contacts), we obtain a table of solutions which contains 2524868 solution, we refined the results which correspond to an elevation greater than $1200 \mathrm{~m}$.

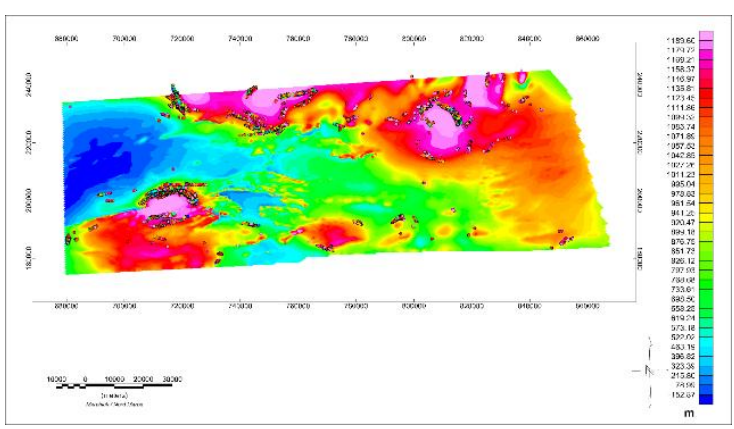

Fig.10: Superposition of the Euler solution map with the magnetic data map reduced to the pole

The map of Euler's deconvolution obtained, presents the position of the sources calculated as circles, with the depths represented by color scale. The Euler deconvolution solutions are located at depths that vary between -152.87 and $1189.60 \mathrm{~m}$ by superimposing the map of Euler's solutions and the map of the reduced magnetic field at the pole of the plain of Tamlelt, we note that the lineaments defined by the Euler solution limit the most important anomalies in the EW direction and then following the direction NW-SE.

\section{Conclusion}

From the analysis of the aeromagnetic data, we identified, the magnetic anomalies existing in the plinth of the plain of the Tamlelt, they are representing a positive pole elongated in the direction NW-SE and a negative anomaly in the direction EW.

Later, we characterized the lineaments affecting this basement through the use of the Euler deconvulation transformation, which allowed us to discover the cracks and faults effecting the Paleozoic basement essentially and superimposed with the magnetic anomalies identified in the map of magnetic data reduced to the pole.

The transformation of Tilt Angle or the angle of inclination allowed to delimit the most important magnetic anomaly (Ain Chair-Mengoub).

The results of this study will be used for mining research and exploration in the Tamlelt area.

\section{References}

1. M. AMAR, A.MANAR, M.BOUALOUL Apport de la cartographie aéromagnétique à l'identification structurale du système aquifère des sources de l'oasis de Figuig (Maroc) Bulletin de l'Institut Scientifique, 
Rabat, section Sciences de la Terre, p. 29$40, \mathrm{n}^{\circ} 34,2012$.

2. Notes et Mémoires du service géologique; Ressources en Eau du Maroc Tome3 Domaines atlasique et sud-atlasique, No231, p.140-149.

3. S. MNISSARHIMYARI, C.HOEPFFNER, M.BENZAKOUR, D.ELHADANI, Étude structurale du Haut Atlas Oriental (Maroc) à l'aide de l'analyse linéamentaire des images HRV (XS) de SPOT,

Télédétection, vol. 2 , n 4 , p. 243-253, 2002.

4. Le secteur des Mines dans la région de l'oriental ; Direction du Développement Minier, p.3, 2008.

5. Mohammed-Rachid HOUARI, Etude structurale de la boutonnière paléozoïque de Tamlelt (Haut-Atlas oriental) : sa place dans la chaine hercynienne du Maroc.p

6. E.Pelleter, A.Cheilletz, D.Gasquet, A.Mouttaqi, M.Annich, A.El Hakour, E. Deloule, G.Féraud, Hydrothermal zircons: A tool for ion microprobe U-Pb dating of gold mineralization (Tamlalt-Menhouhou gold deposit - Morocco), Chemical Geology 245,135-161, 2007.

7. M.R. HOUARI et C.HOEPFFNER, structure des terrains paléozoïques à la limite sud de la chaine hercynienne du Maroc : (Haut Atlas oriental), Africa Geoscience Review, vol.7, N.1, p.39-53, 2000 .

8. C.HOEPFFNER, La tectonique hercynienne dans l'Est du Maroc, thèse présentée à l'université LOUIS PASTEUR, p.151-247,1987.

9. A.PIQUE, A.SOULAIMANI, E.LAVILLE M.AMRHAR, M.BOUABDELLI, C.HOEPFFNER, A.CHALOUAN, Géologie du Maroc, p.111-214,2006.

10. E.Pelleter, A.Cheilletz, D.Gasquet, A.Mouttaqi, M.Annich, A.El Hakour, G. Fèraud, The Variscan TamlaltMenhouhou gold deposit, Eastern HighAtlas, Morocco, Journal of African Earth Sciences, 50, 204-21, 2008.
11. S. P. Anand, M. Rajaram, Aeromagnetic data analysis for the identification of concealed uranium deposits: a case history from Singhbhum uranium province, Indian Institute of Geomagnetism, New Panvel, Navi Mumbai, 410 218, India India Earth Planets Space, 58, 1099-1103, 2006.

12. M. Rajaram, S. P. Anand, Central Indian tectonics revisited using aeromagnetic data, Indian Institute of Geomagnetism, Colaba, Mumbai 400 005, India, Earth Planets Space, 55, e1-e4, 2003

13. I. Boutirame, A. Boukdir, A. Akhssas, F. Boutirame, A. Manar, B. Aghzzaf, Contribution of gravity data and Sentinel-1 image for structural mapping. Case of Beni Mellal Atlas and Beni Moussa plain (Morocco), E3S Web of Conferences 37, 05002, 2018.

14. M. Jaffal, N. El Goumi, M. Hibti1, A. Adama Dairou, A. Kchikach, A. Manar2, Interprétation des données magnétiques du chapeaude fer de Laachach (Jebilets centrales, Maroc): Implications minières, Estudios Geológicos, 66(2) juliodiciembre, 171-180, 2010.

15. G.C Nackers, Analyse des données gravimétriques en forage d'un gisement de sulfures massifs volcanogènes dans un contexte géologique complexe. Mémoire présenté en vue de l'obtention du diplôme de maitrise et sciences appliquées (Génie minéral). Département des génies civil, géologique et des mines Ecole polytechnique de Montréal, p.42-43,2013.

16. S. Soulaimani, Modélisation numérique et évaluation de la réserve du gisement minière de Hajjar (Massif de Guemassa, Marrakech) à partir des méthodes de potentiel, Présentée pour l'obtention du Doctorat National spécialité GéophysiqueGéostatistique, Option : Modélisation et exploration minière, Faculté des Sciences de Kenitra-Maroc, p. 64 ,2017. 
17. M. AMAR, M. BOUALOUL,A.MANAR, Traitement des données aéromagnétique et discussion sur les techniques de filtrage: application au Haut Atlas Oriental du Maroc, Note et Mémoire du Service Géologique $\mathrm{N}^{\circ}$ 577, p.10-15, 2014.

18. A.JILALI, A.RIMI, Y.ZARHLOULE, L.A.OUZZAOUIT, A.E.BARKAOUI, A.CORREIA, J.CARNEIRO, Sur la structure hydrogéothermique de la région de Figuig (Haut Atlas oriental, Maroc) On the hydrogeothermal structure of the Figuig region (eastern High Atlas, Morocco, Bulletin de l'Institut Scientifique, Rabat, Section Sciences de la Terre, $n^{\circ} 36,123-134,2014$.

19. Najib EL GOUMI, Application des méthodes géophysiques à l'exploration minière dans la région de Marrakech(Maroc), présentée à la Faculté des Sciences et Techniques de Marrakech pour obtenir le grade de : Docteur, Université Cadi Ayyad Faculté des sciences et technique, Marrakech-Maroc, p.51-56,2010. 